\title{
The epistemic foundations of injustice: lessons from the Young Marx
}

\author{
Gianfranco Casuso (10) ${ }^{1 凶}$
}

This article intends to show to what extent the early Marxian categories of alienation, ideology and proletariat can serve to better understand current forms of epistemic injustice, as well as, conversely, how the latter can illuminate some unclear aspects of such concepts. In the first part, it will be explained the extent to which Marx's concept of alienation accounts for the experience of an individual in a world to whose norms she is subject, but which she cannot recognise as her own. It will be shown that Marx finds the answer in a form of emancipatory praxis linked to a transformative appropriation of social reality. In order to deepen the understanding of this idea of emancipation, the second part will analyse the Marxian concept of the proletariat. It will be argued that taking up some considerations about the Hegelian figure of the rabble, Marx distinguishes a "liberal" from a "human" form of emancipation. In the third part, a contemporary example will be used to show the usefulness of the young Marx's analyses concerning this dimension of emancipation struggles. In the fourth part, these ideas will be developed further through the concept of epistemic injustice, which has gained great importance in the recent studies that Critical Theory carries out of the different socio-epistemic blocks of an ideological nature that prevent articulating, communicating and overcoming negative experiences that hinder individual self-realisation. In this sense, it will be shown the importance of the Marxian categories of alienation and ideology to theoretically address current forms of epistemic injustice, and, in relation to this, it will be explained the transformative and constitutive function of the excluded in the creation of new sectors of reality through which their demands can be met.

\footnotetext{
${ }^{1}$ Pontificia Universidad Católica del Perú, Lima, Peru. ${ }_{\text {email: gcasuso@pucp.edu.pe }}$
} 


\section{Introduction}

reedom has been-almost without exception-the central theme of modern practical philosophy. Already in Hobbes, Locke, and Kant it is possible to identify a profound concern with the search for the social and political conditions that would enable the individual to be autonomous-that is, her realisation according to the mandates of her own consciousness without submitting herself to the commands of society and the State. However, it is with Hegel that freedom begins to be understood in a more complex way and ceases to be merely that which is opposed to social reality. In this sense, a freer person is not the one who decides by herself what is right or wrong, whether following her own free will or seeking the source of all moral determination in a rational subjectivity of a higher order. ${ }^{1}$ According to Hegel, to be free, a person needs society, since society is the only instance that can guarantee the existence and preservation of the relationships of recognition that enable the constitution and realisation of the individual-not only as selfish subjects that strategically pursue their own goals, but also as beings that need others to develop the interpersonal bonds that constitute permanently their identity (Hegel, 1986b, \$142-157).

Marx, a careful reader of Hegel, was well aware that someone who believes not to need others but as a means to satisfy her desires is an incomplete individual and her freedom is only apparent. Marx, also an enthusiastic reader of Rousseau's Second Discourse, knew that behind the belief that we are the ones who truly choose our own lifepaths, lies the powerful and invisible dictatorship of society. Despite a seemingly unrestricted freedom of choice, Rousseau argues, we still depend on the approval and recognition of others and adapt our preferences and wishes to parameters which we have not chosen and are unable to control (Rousseau, 1997, pp. 170-171). However, this pessimistic tone that traverses the whole Discourse changes when Rousseau discusses the ways of overcoming the pathological character of human relationships in The Social Contract. In this work, Rousseau explores strategies to repair and transform damaged social bonds through an institutional conception that fosters another type of human relations. The aim is to transcend their purely instrumental character and to promote a space where the search for the satisfaction of private interests is not the only thing to bring individuals together, but also sense of a common good expressed through norms and institutions in which they can recognise themselves once again. In this way, a new type of mutual dependence is produced and the social constitutive potential through collective action is released (Rousseau, 1996, pp. 59-60, 121-122).

This assertive aspect of the theory, associated with the constitutive role of mutual recognition, is an idea that Hegel will draw on in order to explain how to overcome the atomistic conception of society and the individual. Hegel considers that such a conception corresponds to the process of withdrawal experimented by the modern subject as a reaction to her inability to recognise herself in the objective reality, since the world of the existing freedom has been untrue to her. Such a subject seeks then within herself a normative criterion of a higher order (Hegel, 1986b, $\$ 138$ ). This rift (Entzweiung) of the mind or alienation from the world has two negative effects for the realisation of individual freedom (Hegel, 1986a). On the one hand, it is the origin of the individualistic tendency-a tendency that Hegel describes in The Philosophy of Right as the foundation of civil society-according to which the subject is unable to see that she is always immersed in cooperative relationships that are not only instrumental but also constitutive (Hegel, 1986b, \$187). However, this rift suffered by the subject is also associated with the following issue: even acknowledging the constitutive role played by the environment with respect to subjectivity and accepting its influence in the production of the individual's interests and preferences, one should not lose sight of the central Hegelian idea that alienation only takes place with respect to a world which one has contributed to produce, usually through not fully conscious inertias and routines. In this sense, the discomfort experienced by the alienated subject is related to the systematic loss of something that belongs to her but that she experiences as alien (Jaeggi, 2014 b, pp. 37-39). It is a process of loss in which individuals cease to recognise themselves in the products of their actions. In both cases, the overcoming of this situation implies that the subject finds herself again in the institutions that apparently only constitute and determine her in a unilateral way. One ought therefore to traverse the path in both directions: allow to be constituted and become aware of the constitutive activity of one's own subjectivity towards the world. This bidirectional movement entails the appropriation of a world that the subject starts to perceive as a second nature: that is, as a world that imposes its own rules and makes impossible for the subject to assume the role of creator of the space that conditions her and regulates her actions.

In this article, I intend to show in what extent the early Marxian categories of alienation, ideology and proletariat can serve to better understand current forms of epistemic injustice, as well as, conversely, how the latter can illuminate some unclear aspects of such concepts. In relation to this, I will highlight both the transformative and constitutive role of those excluded in the creation of new sectors of reality through which their demands can be met, as well as the "universal" character of these demands, which not only makes it possible to legitimise such changes beyond the particular perspective of those directly affected, but also help to reveal hidden normative violations that are harmful and wrong to society itself. In the first part, I will explain the extent to which Marx, following his two predecessors, uses the concept of alienation to account for the experience of an individual in a world to whose norms she is subject, but which she cannot recognise as her own due to a narrow understanding of human freedom and fulfilment. Through the analysis of three key writings of the young Marx, I will look for some clues about the ways of overcoming this alienating relationship of the individual with herself, with others and with the world. I will intend to show that the answer is found by Marx in a form of emancipatory praxis linked to a transformative appropriation of social reality that solves the contradictions that emerge from the unfulfilled promises of modern institutions. With the purpose of deepening the understanding of this idea of emancipation, in the second part I will analyse the Marxian concept of proletariat as developed in On the Jewish Question and Critique of Hegel's Philosophy of Right. I will argue that, taking up some considerations about the Hegelian figure of the rabble, Marx distinguishes two forms of emancipation. The first one-linked to a form of justice that we could call "liberal"-is focused only on the fulfilment of certain existing rights, which respond to the defence of an instrumental and atomistic conception of the human being. The second oneassociated with the overcoming of what Marx calls "injustice as such (Unrecht schlechthin)"-refers to the possibility of making visible sufferings that cannot be decoded through existing social categories because they do not conform to the established liberal parameters. This form of emancipation, which Marx calls "human" in opposition to the political or bourgeois emancipation described above, would have a constitutive or socio-ontological character, since it is oriented towards the transformation of society through the praxis of those who do not find a place in it, and not, as in the previous case, towards the incorporation of individuals into the benefits of existing institutions. In the third part, I will use a contemporary example to show the usefulness of 
the young Marx's analyses concerning the double dimension of the above-mentioned emancipation struggles. I will start with the idea that faced with what Marx calls "universal suffering", there would apparently only be two options. Either it seeks to overcome it by interpreting it according to parameters belonging to the existing order, or it is understood only as a purely subjective malaise, reducing it to whim and arbitrariness. Since Marx discards the first option, the ways of solving that reduction of a human problem (or "universal", in Marx's terms) to a merely private matter remain to be examined. This is what I will develop in the fourth part through the concept of epistemic injustice, which has gained great importance in the recent studies that Critical Theory carries out of the different socio-epistemic blocks of an ideological nature that prevent articulating, communicating and overcoming those negative experiences that hinder individual self-realisation.

\section{Civil society and alienation}

Following Hegel, Marx discusses in On the Jewish Question (1843) the forms of inclusion that a political State ought to guarantee. In the context of the debate with Bruno Bauer that led to this publication, it is stated that Jews should not have to renounce their religion in order to emancipate themselves, thus gaining the possibility of inclusive participation. This was supposedly one of the achievements of the political bourgeois revolution: to relegate religion-as well as any other set of communitarian practices and beliefs - to the private sphere, neutralising the difference and guaranteeing an abstract political equality thanks to a formal Law that only serves particular egoism (Marx, 1972a, pp. 367-370). According to this position, an attempt to embody the ideals of the French Revolution in the political and legal institutions proper of the modern State had already been made. This is what Bauer calls political emancipation; this, however, claims Marx, is still not enough for true human emancipation. ${ }^{2}$

The problem lies in a Law made to fit individuals that are not organically related, a juridical fictitious subject that distorts the idea of the real individual (Marx, 1972a, pp. 356-357, p. 370). In this version of emancipation based on an abstract idea of equality -where it does not matter who one is with respect, for example, of one's cultural belonging or religious beliefs-it is possible to recognise the old Hegelian theme of a civil society understood in a limited way: a society in which the only important thing is to be treated as an individual capable of setting herself goals and achieving them, as well as of guaranteeing the achievement of these goals through contracts protected by the law. This individual is first emptied of her identity through the promise that this will guarantee equal treatment. However, once transformed into an abstract being, she can be moulded as a well-behaved worker and consumer who, also, is convinced that she is free. In this way, the human being is reduced to the bourgeoisie. Like Hegel, Marx highlights the necessity of a wider notion of freedom, a social one, since human emancipation is only possible through the inclusion of real human beings in the social practices and institutions that promote different types of intersubjective relations, all of them equally necessary for their total self-fulfilment (Marx, 1972a: 370).

In The German Ideology (1846) Marx claims that the activity of this real individual-in the totality of her relations with the world - consists in being able to fulfil and recognise herself in the world according to her own faculties (Marx, 1983, pp. 28-30). This is the only way to overcome an alienated existence. In this recognition of the individual's tendency towards the overcoming of alienation, Marx displays one of the most fundamental elements of his thought-that is, freedom understood as the realisation of the human faculties through the activity in which she best relates to the world: labour. According to Marx, there are four essential and necessary relationships for the fulfilment of the individual: the transformation of the natural world to satisfy natural and acquired needs, the relationship with oneself, the relationship with other human beings, and the historical production of the social and institutional conditions that facilitate the achievement of the three previous levels (Marx, 1983). These moments, that ought to be fulfilled simultaneously, cannot be posterior to consciousness, since, according to Marx, the latter "is beforehand a social product and will be such as long as human beings exist" (Marx, 1983, pp. 30-31).

These four levels echo a previous text, edited in 1932, with the title Economic and Philosophic Manuscripts (1844). Already in this work, Marx described the process of the emptying of identity -of reduction and simultaneous imposition of goals, habits, ways of thinking, feeling and assessing-as one of the ways in which alienation expresses itself, making it impossible for human beings to fulfil themselves as individuals. Marx claims that real human beings do not relate to the world only cognitively, through thought, but that they place themselves in reality through all of their senses. The world that appears before the individual-Marx is here indebted to Hegel-is, therefore, an already humanised nature, even though the individual may not always recognise this clearly. Thus, in order to lead a non-alienated life, it must be possible to turn the objects of nature-perceived as something external-into a part of the individual. This notion of appropriation (Aneignung) of the world and of overcoming reification, as well as Marx's thoughts on the nature of labour, lead him to develop an idea of alienation in four complementary directions. Accordingly, alienation would take place regarding the product, which acquires an existence independent from the producer, as an object that no longer belongs to her. Additionally, alienation would occur regarding the individual herself, since the activity she carries out does not allow the full development of all her faculties. This form leads to alienation concerning one's own generic being (Gattungswesen), i.e. estrangement from one's own human nature. Finally, alienation would occur concerning other individuals, since alienated processes of production take place within the context of a distorted and purely instrumental form of human relations (Marx, 1985, pp. 516-518).

On these grounds, Marx points out that, although history is the history of human alienation, is within Capitalism that the situation worsens to the point of becoming intolerable. Thus-he claims-capitalistic productive activity denies humans in almost all their dimensions. Overcoming alienation is a complex process, orientated towards the transformation of the conditions that favour an imperfect or limited fulfilment of human potentialities. Marx's main topic here is the liberation of the individual as a social being. Like Hegel, Marx is against a purely negative notion of freedom, for human beings are only free if they "appropriate their multifaceted being completely, i.e. as total human beings, in each one of their human relations to the world: seeing, hearing, smelling, tasting, feeling, thinking, looking, wanting, acting, loving; to sum up, with respect to all organs of individuality (...). The appropriation of human reality, its behaviour towards objects, is the activity of human reality" (Marx, 1985, pp. 539-540).

Although within Capitalism the proletariat is forced to sell its workforce-suffering, paradigmatically, all the effects of alienation-clearly waged labour in Capitalism is not the means to solve this situation, since this situation results precisely from the impossibility to obtain, through work, the material conditions for self-realisation. This condition of disadvantage is usually associated with the image of the waged worker-its factual, worldly form-but it has a deeper, ontological origin. Certainly, through this figure the proletariat is placed in the specific context of Capitalism, but, even though it can only emerge in this context, 
its revolutionary potential does not seem to be exhausted by this historical configuration: its ontological-constitutive character transcends this configuration. This surplus constitutes the possibility of critique and transformation, that is, of true human emancipation. I will discuss this issue and its relation to Hegel in the following section.

\section{From the rabble to the proletariat: civil society and exclusion} In his Philosophy of Right, Hegel reserves the term rabble (Pöbel) to refer to those who are not only (or not necessarily) materially poor but who have developed a feeling of outrage (Empörung) against society based on their own experience that no matter how hard they try, they will never be able to guarantee their subsistence through their own means nor will they be able to fully take part of social advantages (Hegel, 1986b, $\$ 245)^{3}$. This is a complex form of exclusion that applies to those who must obey the norms of society without obtaining any benefits from it or even being able to recognise themselves as authors of said norms. This rabble has become aware that her social condition is based on the principles of a civil society that is understood as a merciless space of competition, as the kingdom of particularity, where the Law only perpetuates atomism, reproduces already existing inequalities and reduces the complexity of human relations to the satisfaction of private interests, instead of representing a space where free wills come together. Those who are excluded also know that their situation of absolute deprivation depends on the contradictory character of a social structure that obstructs the fulfilment of its own ideals of freedom and emancipation-ideals that society promises to factually guarantee for everyone, universally, though actually they are nothing but an unrealisable possibility for the excluded (Hegel, 1986b, \$230, 237, 244Z).

Marx also analyses this specific mode of exclusion within modern society. ${ }^{4}$ In his short but important work Critique of Hegel's Philosophy of Right (1843) Marx attempts to develop the critical and emancipatory potential concentrated in this subject, who is deprived of her most human character. Although alienation makes no distinction between the rich and the poor, it obviously hurts particularly those who are excluded from the advantages of society. Thus, Marx, following the Hegelian figure of the rabble and a category significantly present in economical history, develops his own concept of Proletariat (Marx, 1972b, pp. 390-391). As in the case of rabble, the proletariat is not reduced to the poor but includes those who feel outraged against a society in which they are unable to find their own place. The proletariat, just as Hegel could also say about the rabble, "does not emerge from naturally produced poverty but from poverty that is produced artificially" (Marx, 1972b, p. 390). Thus, the proletariat gradually constitutes the mass that results from the disintegrating effects of civil society (Marx, 1972b, p. 391). Furthermore, Marx's proletariat is not simply nor directly the working class. Marx defines it rather as "a class of civil society which is no class of civil society" (Marx, 1972b, p. 390). Unlike the form of exploitation to which the waged worker is subjected, the proletariat seems rather symbolise a fundamental or ontological type of exclusion, some sort of empty universality or negativity, which conserves in itself all human possibilities but that socially signals a lack of relation. The proletariat does not represent anything that is considered valuable or valid by society. To society's eyes the proletariat is irrelevant, inexistent. The proletarian-says Marx-is nothing and should be everything (Marx, 1972b, p. 389). She belongs to a sector characterised by "the complete loss of the human being, therefore, only through the complete retrieval of the human being can [she] gain herself" (Marx, 1972b, p. 390).

In Hegel's case, the solution to the problem of rabble cannot be reduced to merely remedying poverty, understood as subjective suffering. Subjective aid against poverty-e.g. through alms or charity-carries a particular and contingent character that conserves unchanged the structure, and does not fight the true cause of the problem (Hegel, 1986b, \$242). Hence, the solution must involve a universal element and be aimed at reshaping practices and institutions throughout society as a whole. The Polizei already has this aim, attempting to regulate society towards common welfare by keeping a system that serves the purpose of the correct realisation of society's tasks of protection and satisfaction of needs. However, only the Korporation is able to create -immanently and not solely through extrinsic regulation, as it's the case of the Polizei-alternative cooperation spaces that reflect the true idea of civil society. If civil society is to fulfil the universal emancipatory potential that, according to its own concept, it should fulfil within the institutions of Sittlichkeit, it should not be understood merely as a system of necessities ruled by the principle of atomism (Hegel, 1986b, \$253). The emergence of the rabble is precisely the symptom of the failure of a civil society that functions "unfettered" according to the abovementioned limited way of understanding it; as Rousseau may well claim, it's a society in which the essential issue is the search for recognition of private subjects who are forced to show that they are something through their income and other socially acceptable external manifestations (Hegel, 1986b). Far from society's own claims, the intensification of this unstoppable search for self-affirmation does not prevent pauperisation nor the appearance of rabble; rather, it maintains and aggravates both. This residual mass that does not enjoy the advantages of an industrialised and increasingly richer society reveals, therefore, the contradiction at the grounds of society itself (Hegel, 1986b). The contradiction takes place between the definition of civil society as a cooperation system aimed at the fulfilment of freedom as part of the ethical order, and the limited institutional embodiment of civil society as a system of private selfishness. Overcoming this contradiction implies immanently deploying the same values on which the idea of civil society is grounded, values which cannot be fully realised if society is understood only as a market. Thus, exclusion has a regenerative potential that leads to the necessity of institutionalising new forms of social interaction and recognition as a way of overcoming such a contradiction (Hegel, 1986b, \$256). It is not a matter of mere inclusion within an already existing structure according to accepted parameters; the point is to develop an ethical potential that lays dormant, but is factually absent from the mechanisms of market society. ${ }^{5}$

For Marx, the solution to the problem that produces the proletariat necessarily requires solving social problems through emancipation. This is why he claims that the proletariat represents "a sphere (...) unable to emancipate itself without emancipating itself from all other regions of society, thus emancipating them all" (Marx, 1972b, p. 390). And he adds, less cryptically, "when the proletariat announces the dissolution of the current world order, it merely speaks out the secret of its own existence, since the proletariat is the factual dissolution of this world order" (Marx, 1972b, p. 391). The fact that the proletariat is already, factually, the dissolution of the current world order has a clear ontological character referred to the proletariat's condition of negativity, as something which is not represented in the factual configuration of reality: it is what forms no part of reality and, nonetheless, is something. Just like the Hegelian rabble-whose awkward presence directed the attention towards the contradictory way of understanding and realising the immanent values of civil society, and demanded an urgent transformation-the proletariat-as the other of society-is in a position to shake up society and reshape it from within, to "dissolve" it on the basis of its own experience. This is even clearer if we consider the rest of the passage: "When the proletariat demands the negation of 
private property, it only elevates to social principle what society has already elevated to proletarian principle, a principle which is already realised in the proletariat, without its intervention, as a negative result of society" (Marx, 1972b, p. 391). The fact that the negation of private property-the fundamental principle of civil society-is fulfilled in the proletariat without its intervention means that the proletariat is subjected to criteria that not only exclude it from the current configuration of society-as its negative result-but also damage the proletariat, without it being aware of this damage, at least at the beginning. Thus, what the proletariat can demand from its position of negativity is its right to existence, but not insofar as it is mediated by given social categories but as the possibility of participating in the configuration of a reality in which it has no place, a reality from which it is alienated. One might say then, that the proletariat does not demand an inclusion that entails the conservation of the social structure: it does not seek anything that civil society can offer in its current form, since this has all been revealed as insufficient, or even counterproductive. Similarly, the proletariat does not only struggle for some particular interest: it is rather "a sphere possessing a universal character due to its universal suffering" (Marx, 1972b, p. 390). Thus, by transcending the particular, since it is not a proper part of society, the proletariat is able to achieve structural transformations that will-universally-affect society as a whole; transformations aimed at the better realisation of social freedom.

This said, it may now be easier to grasp the meaning of Marx's words quoted above according to which the proletariat cannot emancipate itself without emancipating all other regions of society, since its universal character transforms its struggles into human struggles. This is also why Marx's claim makes sense: the proletariat "does not demand any special right: since it does not suffer any special injustice, but rather injustice as such (das Unrecht schlechthin), it can no longer claim any historical title but only its human title" (Marx, 1972b). From this perspective, justice would not be directed towards achieving this or that entitlement according to already set social criteria. In other words, for the proletariat justice does not only represent a particular vindication nor a better distribution of certain social advantages matching alleged group interests. This is so because the proletariat is not merely a particular class of society among others, competing with them (cf. Buchanan, 1984). Justice "as such" applied to all of society refers rather to the constitution of a fairer order that fosters the universal realisation of social freedom. It is, therefore, social justice. As in Hegel's rabble, it is not enough to deploy particular solutions centred on the subjective suffering of those constituting the proletariat. For, as we have already seen, these problems originate from contradictions rooted in society itself. Thus, even when their demands seem to be linked only to a particular experience, these demands ought to be recognised, in the long term, as relevant for society as a whole. This is what Marx wishes to highlight as the central element of the proletarian struggle, for it is the proletariat that must transit from an experience of suffering-initially assumed as purely subjective-towards the social perception of this suffering as a "universal suffering".

At this stage, we may say that this road and the road of ideology critique travel in opposite directions. The latter certainly must help to unveil the purely particular character of hegemonic interests of a part of society, illegitimately hidden behind a façade of universality by fallaciously identifying the interest of a part with the interest of all. In the last two sections, I will attempt to reconstruct with further detail the relationship between this universal claim for justice and the problem of ideology as it is to be found in Marx's thought, and I will underline the importance of this for a study of the critical role of the particular experiences of suffering. ${ }^{6}$

\section{Suffering and emancipation: the role of particular experience}

If we wish to understand the actuality of the critical potential of the Marxian approach to the forms of human emancipation, we should first determine who could be considered excluded today in the sense mentioned above; that is, who are those with no place in society allowing them to realise themselves as free persons. In raising these questions we will possibly think of all those people whose suffering, though legitimately human, remain misunderstood and unattended by the rest of society; those for whom social institutions and practices have ceased making sense and no longer represent a channel for their self-realisation, thus becoming a cause of oppression or marginalisation. For the sake of clarity, I will summarise in six points what was said about the elusive Marxian category of the proletariat in the quoted texts: (1) To the extent that the proletariat is a class that is not a class in society-in the sense of not being represented in it-it is difficult to determine the nature of her suffering, since the existing categories do not do her justice. (2) Overcoming suffering is problematic because it is usually interpreted only as of the result of the inability of those affected to achieve the current standards that define self-realisation. (3) This constrained reading does not respond to an arbitrary interpretation of any particular kind, but rather represents the general way of understanding reality, instantiated in the current practices, norms and institutions that define, among other things, what is just and unjust. (4) By not committing any special injustice but rather injustice as such, their suffering does not demand any special right. This raises the question about the conditions of their emancipation if it is not enough to subsume the particular of suffering in pre-existing general categories (5) Rather than applying special forms of justice with dubious claims of universality, it is about reformulating the criteria of justice in the light of peripheral experiences. In this sense, a change must be generated on two intertwined levels to do justice to the suffering of the proletariat and achieve her emancipation, understood as overcoming her alienated condition. On the one hand, the uniqueness of suffering requires the transformation of social categories so that the rest of society can understand it. But since the proletariat cannot be emancipated without emancipating all other regions of society, such a transformation entails, in addition to this epistemic dimension, an ontological dimension. The recognition of the existence of the proletariat, we have seen, already implies the dissolution of the factual order of the world, since the suffering that is inherent to her cannot become manifest without the categorical and material restructuring of such order. (6) But this does not mean that any arbitrary demand can or should lead to social transformation. Accentuating the universal character of the suffering of the proletariat avoids understanding it as something completely alien or external to society. ${ }^{7}$ Rather, it is that the particular experience makes it possible to make a latent but hidden problem in the social fabric accessible to everyone, so that, effectively, this problem cannot be solved for her without also solving it for everyone.

Before developing this last point in more detail, I will try to illustrate what has just been exposed with an example taken from the reality of many countries with a colonial past, constitutionally liberal, but with primary-exporting economies. Imagine that a mining deposit is discovered in the territory of a traditionally agricultural community, and then the State and the company decide to negotiate its relocation by applying fair forms of compensation. In the best of cases, this negotiation is usually carried out within the framework of criteria of justice associated with legitimate commercial transactions-since land is seen as a transferable asset governed by property or concession rights, and on which current regulations to determine legal actions such as the determination of the fair price or the conditions of the usufruct are applied. However, it is often the case that the type of 
relationship that the original inhabitants maintain with their environment is not that of ownership or usufruct over an asset: from their worldview, such an environment has an ethical sense that is difficult to replace by monetary compensation. The inability to understand this situated perspective from alternative criteria of justice to those of the market economy usually generates forms of suffering that lead to social conflicts that are difficult to solve (Bebbington, 2012; Casuso, 2014; Damonte, 2016).

The situation is therefore problematic, not only because it aggravates the suffering of a particular sector, but also because the institutions and their mechanisms for dialogue are revealed as incapable of stopping the growing demands. Suffering makes it possible here to show a structural defect in official policies to deal with different worldviews whose demands do not fit the parameters of commercial transactions. If we consider that solving problems dialogically is precisely the objective of such policies, we will see that this marginalised sector reveals the limitation of institutions to carry out their own ends effectively. It could even be added that, as part of a liberal state, such institutions are usually formally committed to respect for difference, tolerance, democratic inclusion, and other principles, the realisation of which is nevertheless revealed to be systematically hampered by their own epistemic and material structures. Ideally, then, suffering can favour the visibility of new problematic situations that will then be revealed as relevant not only for the members of the original population but for the system itself. ${ }^{8}$

As we have seen, Marx considered that authentic emancipation requires the active participation of those whose suffering is universal, that is, those subjected to a type of injustice that cannot be exclusively identified with the interests of a certain group recognised by society, and whose demands have been previously and explicitly stated, and accepted as legitimate. The core of this Marxian intuition can be outlined in two closely linked ideas.

First, emancipation requires that the problems of those affected be recognised as real problems by and for the rest of society. However, the condition of the affected cannot be overcome solely through the paths already opened by previous demands for which there are concrete solutions embodied in actual institutions and norms. In other words, it is not an issue of forcing the comprehension of a negative experience in order to make it fit a preexisting typology based on schemes of interpretation that define what an authentic problem and a legitimate demand are. These preconceived schemes usually ignore the singularity of the experience at hand as well as its social-constitutive nature. For this same reason, the solution to this kind of problem does not lie simply in allowing the incorporation of the excluded ones into the set of the beneficiaries of the socially recognised advantagesthose that Marx in On the Jewish Question associates with bourgeois values fixed to match a particular type of individual whose interests and goals are taken for granted insofar as they match those of a society reduced to a market. Instead it is central to further changes applicable to the structure of society itself, thus avoiding blockages and possible regressive effects resulting from the denial of the demands of the excluded. ${ }^{9}$ This transformation process makes society permeable to demands which have not yet been entirely decoded, it allows the resignification of what is considered socially valuable, and widens the understanding of the individual and her needs without reducing her to her instrumental aspect. The possibility of fulfilling such a transformative process corresponds, to a great extent, as we have seen, to the concept of justice as such that Marx mentions in his Critique of Hegel's Philosophy of Right. The struggle for emancipation has, thus, an inherent constitutive role which consists, precisely, in the creation of new ways to get the approval of those demands that remain unheard in society and, therefore, do not exist. The cited example refers to real afflictions of human beings whose experiences, in spite of seriously compromising essential elements of their lives, have not been officially classified by society as problematic. This leads to another issue involved in the Marxian conception of the universal character of emancipation.

Second, although the problems relate to ailments with a clearly subjective side, their intrinsically universal character must be recognised, since they are not purely arbitrary demands but the expression of real experiences. This is rarely perceived by society since there is a tendency to diagnose ailments according to preexisting categories that allow distinguishing normal from deviated behaviour. In this way, anything that does not match those criteria is simply demoted to the realm of arbitrariness. Accordingly, these demands are not considered socially relevant but only the product of some delusion by a damaged psyche tending to divergence. The only option then seems to be turning to the traditional methods used to diagnose cognitive pathologies or some other kind of individual deficiency in order to normalise subjects, make them mentally healthy and functional, to put them once more at the service of social reproduction. As it was shown, already Hegel, when analysing the adequate means to alleviate the negative effects of the "normal" functioning of civil society, warned about the insufficiency of the solutions directed to the relief of purely individual suffering. On the contrary, the universal nature of emancipation at this level has to do with the possibility that the affected manage to articulate and express, in a manner that is still understandable for the rest of society, their negative experiences which, are ultimately based on a problematic social configuration that insists on remaining unchangeable.

What I wish to hold in this section is that these two ideas lead to Marx's core intuition, related to the double aspect of the emancipation struggles embodied by the proletariat. The problem lies in the fact that the proletarian experiences are interpreted (i) either according to parameters belonging to the existing order, as corresponding to group interests already recognised by the society, (ii) or as purely subjective, reduced to a whim and arbitrariness. In neither case does the social order manage to understand the singularity and urgency of these experiences, nor does it interpret them as a valid malaise caused by something in society that ought to be transformed. It is clear that at this stage we find an irreconcilable rupture between subjectivity and factual social order that makes the achievement of universal emancipation impossible. Thus, social struggles must bring together the subjective aspect associated with the authentic expression of suffering and the social-ontological aspect associated with the possibility of overcoming the suffering through its recognition in social reality, albeit without it meaning interpreting the situation according to established categories. The "universal" character to which Marx refers, then, has nothing to do with the fact that everyone should be affected equally by the same suffering, nor only with the fact that everyone has been able to empathically take the suffering of others seriously. ${ }^{10}$ In addition to this last condition, which could be better expressed as the need to produce knowledge to include previously misinterpreted or ignored experiences, the universal nature of suffering also refers simultaneously to the possibility of generating a necessary social transformation. This transformation is effectively a requirement for the satisfaction of the demands of those directly affected, while these demands help to reveal limitations and contradictions whose resolution represents a favourable change for other social members: their emancipation thus requires a social change whose necessity they help to show from their particular experience. Hence, universality requires recognising the transformative and constitutive function of the excluded: they must play a fundamental role in the creation of new social sectors in which their experiences and demands acquire meaning and their discomfort 
may be overcome. As I will explain in more detail in the next section, these difficulties in articulating and expressing such experiences due to a distortion or a deficit of the available socioepistemic resources, remarkably resembles the concept of epistemic injustice developed in the last decade to account for different types of second-order social problems. ${ }^{11}$

\section{Alienation, ideology and epistemic injustice}

From what we have learned in the first section, it is now possible to notice that the problem of alienation is defined by the same two aspects discussed above. In what follows I will sum up this issue on the basis of my previous explanation.

The first aspect refers to the failed relation of the individual to a reality that she cannot recognise as the product of her activity and that reduces her, functionally, to a mere instrument at the service of social reproduction. The general idea is that the individual loses control and influence over the world around her, and is delivered to anonymous forces that configure and determine her life. Here alienation consists in the fact that, with her actions, the individual cyclically recreates the material conditions of the forms of life that certainly belong to her, but that she is unable to recognise as her own nor as adequate for her full realisation.

The second aspect, closely linked to the previous one, refers to the relation of the individual to herself. That is, the image that the individual makes of herself on the basis of her participation in a regulated society constituted according to market parameters. This society-as we have seen in the introduction when discussing Rousseau and Hegel-favours a subject for whom all the others are basically only a means to achieve her own ends. This subject, furthermore, finds no way of leading her life other than adapting her desires, interests and entire personality to certain social worth criteria and pre-configured roles. This produces a surplus that remains unsatisfied in a reality that constantly feeds her back a distorted image of herself. As we have noticed from the example in the preceding section, this is the reason why several of her experiences and demands are not recognised as real ones by society, questioning not only their authenticity but also the subject's own self-understanding, to the extent that they don't match the standing social parameters. Thus, society prevents the individual from perceiving her own life as something other and richer than a simple functional element for social reproduction.

In this double dimension of alienation it is possible to identify the two elements of the emancipatory struggle discussed in the previous section. But there is even more. As we shall see, the impossibility of changing those material conditions as well as the epistemic blockages and distortions associated with this impossibility is none other than what is usually known, in the language of Social Philosophy, as ideology.

According to Jaeggi, ideology refers to every system of practices and beliefs that appears to social agents as true but nonetheless, due to its complex historical origin, entails potential contradictions or inconsistencies that are usually overlooked. This does not mean that ideology is something essentially false hiding some underlying truth. From the agents' perspective, ideology is only the set of social meanings that regulate their daily social behaviour (Jaeggi, 2009, p. 64, 67). Thus, ideology has a tacit and unquestioned truth foundation but it is also potentially open to correction. As such, ideology would be problematic when it blocks the possibility of revising a system of beliefs, thus preventing the resolution of latent inconsistencies which are already negatively affecting people's lives, producing several forms of pathological relations usually described as domination, exploitation or oppression. What ideology does, then, is to reinforce the appearance of indisputable harmony and internal consistency of the forms of life, presenting them as unproblematic and, therefore, as an unquestionable second nature (Jaeggi, 2009, p. 72, 80 ). This notion varies from Marx's classic version is an important aspect: for Marx ideology refers almost exclusively to a form of naturalisation of reality that generates the material and epistemic conditions needed so that the interests of a part of society manifest themselves as universal interests, resulting in the commitment of the dominated ones to a social reproduction that ultimately contradicts or blocks the realisation of their "true" interests (Marx, 1983, pp. 26-27, 36, 46). However, as Marx claims - these interests cannot be simply equated to any kind of concrete ends whose content is fully accessible to the social agents. These interests must rather be linked, as we have seen, to a special kind of demand proper to an equally special kind of social existence: the proletariat. That is, those excluded that more directly suffer the consequences of alienation, consequences that are precisely hidden by ideology. According to this, the process that allows knowing what is authentic or true in the interests cannot be previously determined turning to an alleged essential nucleus of truth grounded in the pure certainty of the subjective experience or in a factual reality that represents an external normativity. ${ }^{12}$

At this stage and considering the previous discussion, I would like to go into detail about two themes that will allow a better understanding of the relationship between ideology and alienation, and of the importance of this relationship for studying the critical, epistemic and emancipatory role of particular experiences of suffering.

The first theme is related to the way in which, similarly to alienation, the critique of ideologies operates in the point of encounter between the subjective element of the demands and the social reality in which these demands acquire meaning and ought to be heard. As we have seen, the critique is developed immanently as discomforts that directly affect people's lives emerge. These discomforts-and their derived sufferings-signal a social malfunctioning that ideology tends to systematically hide under the appearance of normality. Thus, as it has been suggested in the previous section, the neutralisation of these negative effects requires going down the path in an opposite direction than the one followed by the critique of ideologies as more or less naturalised systems of beliefs. (i) According to the Marxian approach, if ideology explains the surreptitious imposition of the interest of the dominant class on society, so that even the dominated commit voluntarily to its defence, critique will imply unmasking the false belief in the universality of the interests, in order to deconstruct it and reveal their particular character. (ii) However, there is another kind of ideological concealment that we have been exploring: in it, naturalisation prevents certain demands from being articulated as the expression of legitimate experiences of suffering. This is the effect of a social blockage that only recognises those expressions and practices that have already taken on a factual shape, and are already regulated by norms within accepted institutions. In other words, ideology makes it impossible for subjective suffering resulting from a determinate social configuration to be universally recognised.

This leads us to the second theme. If the blockage refers to the impossibility of transiting from the particular experience to its acceptance as a matter of common interest, then an important element of critique must be linked to the acceptance of the social relevance and the authenticity of the individual experiences. Let us consider once more the example of the previous section. In that case, we find experiences affecting the conditions of selfrealisation of concrete persons whose situation worsens to the extent that they are unable to articulate or express their experiences due to ideological blockages. These not only prevent members of society from recognising these experiences as authentic, and social structures from decoding this new 
information, but they also prevent the agents themselves from becoming fully aware of the kind of malaise they suffer. I wish to call attention to the fact that this way of understanding such ideological effects is highly similar to epistemic injustice. ${ }^{13}$

Indeed, this form of injustice is produced when an individual is unable to comprehend or express her discomfort after a negative experience because society has not produced yet the categories that denote such an experience. According to Miranda Fricker, epistemic injustice involves two aspects. The first one, the testimonial, takes place when someone does not recognise the value of someone else's speech due to pre-existing prejudices about her identity. As a result, the authenticity of the experiences of the individual and the legitimacy of her demands are questioned (Fricker, 2007, pp. 17-29). This agential character-though not always intentional-of injustice is complemented by a structural aspect called hermeneutical by Fricker. This takes place when, due to blockages concerning the capacity for internal review and innovation of the forms of life, the necessary channels for the determination, comprehension and communication of some need are not created, affecting negatively people and groups in a significant manner (Fricker, 2007, pp. 147-152). While in the first case it is about the persistence of a distorted or unilaterally imposed knowledge due to ideological apparatuses, in the second it is about the absence or insufficiency of knowledge.

Although this is not necessarily so in Fricker's version, from the approach to the theory of ideology that I have been forwarding, these two aspects are organically intertwined. ${ }^{14}$ This is so because, in order to struggle non-intentional testimonial injustice, it does not seem enough to expect a change in attitude from the agent carrying out the act of injustice nor to appeal to her goodwill. It is rather necessary to break up the blockage that operates on the forms of life at the hermeneutic or structural level. In this way, in order for a person to be able to articulate a need, and be trustworthy when expressing it as a legitimate demand within a social order that lacks the categories to understand it, it is necessary to unblock and reconfigure the social elements that hinder that experience from being recognised as valid. Only this could produce the material conditions-and, with them, the criteria - for a more adequate interpretation and solution of the problems. Thus, in addition to the critique of ideology, which basically fulfils a negative or unblocking function, the corresponding capacity to produce new social knowledge is also required. ${ }^{15}$ As we have seen, this is also the case of the critical and social-constitutive role of the proletariat for Marx.

One of Fricker's best-known examples is the meanwhile famous case of Carmita Wood, an African-American single mother who was forced to leave her job at Cornell University due to sexual harassment at a time when such a term had not yet been coined. In addition to the discomfort, whose physical and psychological manifestations she could not understand or explain due to the lack of social categories, was added the misunderstanding of a society that tended to diagnose her condition as an unjustifiable arbitrariness, which also prevented her from accessing the corresponding social benefits for having had to leave her job (Fricker, 2007, p. 150). This example, like the one previously mentioned in relation to Marx, allows us to observe that the production of knowledge that social transformation entails not only enables the affected person to understand her suffering and the society to decode it, but also creates the appropriate conditions to stop the proliferation of other similar cases in the future. But although both examples coincide in the need to produce knowledge as a requirement for the attention of demands, what is not always so clear in Fricker's position is the way in which the validity of such demands can be legitimised beyond the subjective perspective of the person who suffers them. Perhaps a hint to understanding this is provided by Fricker by distinguishing between these described forms of hermeneutical injustice and incidental injustice, that suffered by an individual who, unlike Wood's case, is not systematically prevented, because of her identity, from being considered an agent suitable for the production of knowledge (Fricker, 2007, p. 156). Thus, unlike this incidental case of injustice, in the two examples presented we are faced with a situation of pre-existing inequality that places the individual in a disadvantageous position to participate in social-constitutive processes. But in addition to this it is necessary to recognise that suffering is produced by the same circumstances that one seeks to transform, as well as that knowledge about the historical origin of such circumstances is not only possible but also necessary. In this way, part of the knowledge that must be generated in view of emancipation is aimed at becoming aware of the circumstances of the emergence of those structural conditions in which the systematic suffering of some individuals is sustained. In other words, the knowledge must be reached that the real situation of epistemic disadvantage is due precisely to the way in which the categories have been produced in the past. This prior situation of disadvantage, which Fricker calls "hermeneutical marginalisation" (Fricker, 2007, $152 \mathrm{ff}$ ), is, therefore, capable of being corrected through different mechanisms of knowledge generation (Fricker, 2007, p. 150). And at this point the lines cross again, because for both Marx and Fricker it is necessary to organise spaces between individuals who share negative experiences and similar situated social positions-be these unions, cultural communities, women's associations or any other form of grouping that enables the exchange of experiences and information on similar problems. Taking into account the emancipatory and social-constitutive role that Fricker recognises in these groups-for example, by explaining that it was precisely this type of group interaction formed around cases such as Carmita Wood's that initiated the process of collective creation of the notion of sexual harassment-it can be assumed that she would have no problem recognising at least two things. Firstly, that the creation of knowledge for emancipatory purposes is not a process originated from pure subjectivity to later find ex nihilo ways of expression: It presupposes rather the need for self-organisation aimed at the collective and transformative appropriation of the circumstances that generate and reproduce current knowledge. Secondly, that the results of such a transformation not only benefit the individual or the groups initially affected, but that all epistemic innovation-as the one involved in the creation of the category of sexual harassment-is necessarily linked to a very complex series of socio-epistemic changes that operate differently in different contexts (Jaeggi, 2017, pp. 29-30; Haslanger, 2021, pp. 16-17). The recognition of the harmful and wrong of sexual harassment is associated, for example, both with the revision of stereotypes related to female identity or the questioning of power relations at work, as well as the adoption of more inclusive interpretations of the notion of respect or the use of more egalitarian conceptions to define hierarchies. The wide range of resources modified or used so that the new categories acquire meaning and are eventually accepted is what must be mobilised during the experiential processes promoted by organisations and social groups. This, as we have seen, ends up also favouring other groups initially not involved, in addition to the fact that, as occurs with the generation of new ways of understanding labour relations, it contributes to a better understanding of already accepted values (such as respect for dignity) or to enhance more horizontal relationships regardless of the place occupied in the hierarchy. This is what occurred also in the previous example, where the demands generated around the mining conflict not only ended up providing those affected with ways of expression but also generating social changes that involved, in many cases, transformations in the ways of understanding and carrying out tacitly accepted democratic values. This, in the medium and long term, is what could neutralise the proliferation of similar cases, as well as reveal to the rest of society that its institutions and the practices derived from them 
systematically prevent the realisation of the values that they supposedly embody (Honneth, 2011). In this sense, then, suffering not only has a particular character associated with an easily identifiable interest that has been violated but also has a universal character, insofar as it makes it possible to reveal, beyond easily accessible evidence, that something in society it needs to be transformed for reasons that derive from its own functioning, that is, for immanent reasons.

\section{Final remarks}

I would like to conclude with a brief summary of this paper's central thesis and add some complimentary thoughts on the relationship between epistemic injustice and the Marxian notions of alienation, ideology and the emancipation of the proletariat.

Social critique allows apparently arbitrary demands to be considered socially relevant. When society has not developed the required categories for this purpose, the experience of the affected ones must, from the condition of exclusion, contribute to making such demands visible. However, frequently even in the presence of symptoms of a situation of suffering that affects the lives of the subjects, the systems of beliefs on which their forms of life are based are rarely reshaped to make place for such experiences. Thus, the experiences cannot become understandable for the affected ones nor for the rest of society.

It is possible to identify two different orders in this description. The first one refers to problems generating malaises that directly affect people in a way that is relevant for their self-realisation. The second-order refers to the social and cognitive blockage that prevents such ailments from being taken as problems. According to our discussion, this last issue is similar to the concept of epistemic injustice, in so far as it points towards an ideological flaw that makes it impossible for members of society to perceive a given situation as problematic. In this way, this form of injustice is linked to an ideological blockage of the second order. ${ }^{16}$ Thus, one of the basic functions of social movements and other similar forms of organisation is to organise such experiences so that they acquire enough strength to be considered meaningful and publicly relevant by the rest of society. Hence, their main critical function is associated with a second-order of normativity.

As I have tried to show when Marx talks about injustice "itself" or "as such" in his Critique of Hegel's Philosophy of Right, and when he talks of a type of emancipation that cannot be reduced to its purely political or bourgeois form in his On the Jewish Question, he also seems to be referring to the second order of problems. This is so because such a form of injustice is not referred directly to concrete problems already typified as such and that are, therefore, relatively easy to identify. Marx seems to be thinking of something different since he considers that the object of critique should be the social order itself to the extent that it presents itself as the perfect consummation of the liberal ideals, which are erected as the only criterion to determine which social problems and demands should be considered legitimate. The truth is, Marx would say, that this reified social order only reproduces the material conditions, blocking every possibility of making visible the necessities not adjusted to established parameters. And, in this way, this social order perpetuates the pre-existing ideological blockages. Then, Marx refers to the impossibility of human emancipation and development under the current historically constituted conditions of capitalism, precisely because the existing normative structures generate a restricted vision of the individual and the world, which produces the four varieties of alienation previously studied and blocks all other social perspectives that do not conform to that view. In this article, I hope to have contributed to some extent to show how the categories of alienation, ideology and proletariat used by the young Marx can illuminate some aspects of the social dynamics associated with the revelation of forms of injustice that are difficult to perceive because of ideological blockages and the absence of sufficient relevant epistemic resources to understand and express them. Additionally, I hope that the elements of the epistemic injustice approach presented (such as the requirement of knowledge production) have served to clarify some conceptual gaps in the aforementioned Marxian categories and that this two-way approach somehow contributes to future theoretical efforts to link both currents of thought.

Received: 17 December 2020; Accepted: 17 May 2021; Published online: 04 June 2021

\section{Notes}

1 For a detailed reconstruction of the different levels implied in this more complex kind of social freedom developed by Hegel, see Honneth (2011). Rahel Jaeggi defends a similar thesis but concerning the concept of alienation, understanding it as opposed to a notion of "appropriation" that also presents itself in its most fulfilled form in the Hegelian notion of social freedom (Jaeggi, 2014b). In relation to Marx, see also Jaeggi, 2013.

2 "Political emancipation is, of course, a big step forward, but it is not the final form of human emancipation in general. It is the final form of human emancipation within the existing world order" (Marx, 1972a, p. 356).

3 This deprivation suffered by those excluded, as Hegel claims, takes place in several dimensions: "it is impossible for them to claim their rights through formal justice (...) due to the costs linked to the administration of justice. Moreover, they also face great disadvantage regarding religion, health and education" (Hegel, 1983, p. 118). On this issue see, Hardimon (1994)

4 Although Marx does not use the term "exclusion" systematically, the way he defines the proletariat allows us to identify in this concept certain elements associated with a contemporary socio-ontological approach to exclusion. I have developed in detail the relationships of this notion of exclusion with Hegel and Marx in Casuso (2016, 2017, 2018).

5 I have developed these ideas in more detail in Casuso (2016, 2018). For an interesting additional insight into the relationship between the Hegelian Pöbel and the Marxian Proletariat (see Ruda, 2011).

6 According to the now-famous reconstruction of the tasks of the Frankfurt School that Axel Honneth carries out, society is pathological when it meets a double condition: on the one hand, its institutions, norms and practices block the realisation of a series of ideals embodied in that same society, and, on the other hand, such a condition makes it difficult for these blockages to be perceived, thus reducing the capacity of social actors for reaction. Since the social conditions themselves hide the anomaly in such a way that it cannot be questioned, a critique of social anomalies has to be connected with an explanation of the processes that have contributed to veiling them. Honneth argues that the indicator that can give us the clue that a social situation hides pathological features is suffering. Suffering should be, then, a kind of "symptom" of social pathology. However, and here is where the difficulties begin, immediately appealing to the individual experience of suffering does not necessarily allow us to get out of the trap, because the dual pathological condition of society is so powerful that under a veil of normality it could even block the emergence of every possible symptom. For a detailed reconstruction of the role of social suffering in critical theory, see Honneth (2009) and Renault (2017). On the role of "particular moral experiences" in relation to an immanent critique of society, see Stahl (2017) and Renault (2020).

7 This coincides with the idea that alienation does not mean that the subject does not belong at all to a social order, but is unjustly separated from an order that constitutes her and should belong to her. In this sense, appropriation as an overcoming of such alienation is only possible through the transformation of said order.

8 The example is presented for explanatory purposes only. However, it groups together some of the main characteristics that define different kinds of real social conflicts originated by the extractive industry in Latin America. For more details about the complexity of the more specific cases, see e.g. Bebbington (2012) and Damonte (2016). A presentation of different types of social movements whose motivations can be explained with Marxian categories is found in Barker et al. (2013).

9 On these ideas of second-order progress and regression, concerning the possibility or impossibility of unblocking the ideological veil of the forms of life, see the discussion between Allen and Jaeggi in Allen et al. (2016).

$10 \mathrm{I}$ am grateful to an anonymous reviewer who drew attention to the possible ambiguity of my use of the term "universal" in relation to Marx. Based on his/her observations, I have tried to further develop this point in this and the next section. 
11 On the epistemic foundations of social criticism in relation to the idea of social pathologies as second-order disorders, see Zurn (2011). An interesting critique of this approach can be found in Laitinen (2015).

12 Honneth claims that there are two strains derived from the idea of reflexive freedom (understood as the realisation of a purely negative freedom) developed by Rousseau. The first is associated with the concept of self-determination and is defended by Kant and later developments by Habermas and Apel. The second one highlights the notion of self-realisation and is defended by Herder and contemporary existentialism linked to the ethics of authenticity. The problem is that none of them manages to institutionally widen the reflexive concept of freedom enough for it to close the gap between a purely subjective freedom and an objective normativity. This, according to Honneth, is only achieved by the idea of social freedom that can be reconstructed on the basis of the structure of the Hegelian Sittlichkeit (Honneth, 2011, pp. 44-80). As I have already suggested, Jaeggi also considers a double path to explain the possibilities of a critique of alienation (as opposed to some form of freedom). These derive, according to her, from two elements found in Rousseau-the ideas of social freedom and of authenticity. These two elements, after being reshaped by Hegel through the incorporation of the Kantian ideals of autonomy and universality, have continued their course in the shape of a critique of the naturalisation of the social world and its necessary appropriation (Marx), and of the ideal of a life authentically inherent to the mode of existence in the world of the Dasein (Heidegger) (Jaeggi, 2014b, pp. 6-21).

13 Robin Celikates has recently claimed, for example, that epistemic injustice, at least in Miranda Fricker's version, is a more limited (or "less deep") way of understanding the functioning of ideology, and that it does not exhaust the greater conceptual content of the concept of ideology—-key to a critique of society (Celikates, 2017).

14 For a complete view of the current developments around this concept, see Medina (2013), Kidd et al. (2017) and Brady and Fricker (2016).

15 For a recent approach to this distinction between the negative and the positive (or productive) role of social criticism, see Stahl (2017) and Renault (2020).

16 For a thorough and very useful distinction between first-order and second-order problems, mainly with respect to Hegel, Marx and Dewey, see Jaeggi (2014a, pp. 200-253). On this type of epistemic blockages as social pathologies, see Zurn (2011), Laitinen (2015) and Freyenhagen (2018).

\section{References}

Allen A, Jaeggi R, von Redecker E (2016) Progress, normativity, and the dynamics of social change: an exchange between Rahel Jaeggi and Amy Allen. In: Grad Fac Philos J 37(2):225-251

Barker C, Cox L, Krinsky J, Nilsen AG (eds.) (2013) Marxism and social movements. Brill, London

Bebbington A (2012) Social conflict, economic development and extractive industry evidence from South America. Routledge, New York

Brady Michael, Fricker Miranda (eds.) (2016) The epistemic life of groups: essays in the epistemology of collectives. Oxford University Press, Oxford

Buchanan A (1984) Marx and justice: the radical critique of liberalism. Rowman \& Littlefield, London

Casuso G (2014) Una propuesta para el análisis de conflictos sociales en términos de deliberación, agencia y reconocimiento. El caso de la minería en el Perú. In: Desafíos éticos en los negocios. Fondo Editorial Universidad del Pacífico, Lima, pp. 23-34

Casuso G (2016) Kooperation und Exklusion. Zur Aktualität von Hegels Korporationsbegriff. In: Ellmers Sven, Herrmann Steffen (eds) Korporation undSittlichkeit. Zur Aktualität von Hegels Theorie der bürgerlichen Gesellschaft. Wilhelm Fink, Paderborn, pp. 141-155

Casuso G (2017) Power and dissonance: exclusion as a key category for a critical social analysis. In: Constellations 24(2):608-622

Casuso G (2018) Exclusion. In: Krisis 2:50-52

Celikates R (2017) Epistemische Ungerechtigkeit, Loopingeffekte und Ideologiekritik. Eine sozialphilosophische Perspektive. In: WestEnd 2:53-72

Damonte G (2016) Estado, gobierno y extractivismo en el Perú. In: Quero Morgan (ed.) El Perú en los inicios del siglo XXI: Cambios y continuidades desde lasciencias sociales. UNAM, México DF, pp. 13-28

Freyenhagen F (2018) Critical theory and social pathology. In: Hammer Espen, Honneth Axel, Gordon Peter (eds.) Routledge companion to the Frankfurt School. Routledge, London

Fricker M (2007) Epistemic injustice: power and the ethics of knowing. Oxford University Press, Oxford

Hardimon M (1994) Hegel's social philosophy: the project of reconciliation. Cambridge University Press, Cambridge

Haslanger S (2021) Political epistemology and social critique. In: Oxford studies in political philosophy (in press).

Hegel GWF (1983) Vorlesungen über Naturrecht und Staatswissenschaft (Wannenman Nachschrift 1817/18). Meiner, Hamburg

Hegel GWF (1986a) Phänomenologie des Geistes, Werke 3. Suhrkamp, Frankfurt/M

Hegel GWF (1986b) Grundlinien der Philosophie des Rechts oder Naturrecht und Staatswissenschaft im Grundrisse, Werke 7. Suhrkamp, Frankfurt/M
Honneth A (2011) Das Recht der Freiheit. Grundriß einer demokratischen Sittlichkeit. Suhrkamp, Berlin

Honneth A (2009) A social pathology of reason: on the intellectual legacy of critical theory. In: Pathologies of reason: on the legacy of critical theory. ColumbiaUniversity Press, New York, pp. 19-42

Jaeggi R (2009) Rethinking ideology. In: De Bruin Boudewijn, Zurn Christopher (eds.) New waves in political philosophy. Palgrave Macmillan, London, pp. 63-86

Jaeggi R (2013) Was (wenn überhaupt etwas) ist falsch am Kapitalismus? Drei Wege der Kapitalismuskritik. In: Jaeggi Rahel, Loick Daniel (eds.) Nach Marx.Suhrkamp, Berlin, pp. 321-349

Jaeggi R (2014a) Kritik von Lebensformen. Suhrkamp, Berlin

Jaeggi R (2014b) Alienation. Columbia University Press, New York

Jaeggi R (2017) "Resistance to the perpetual danger of relapse": moral progress and social change. In: Allen Amy, Mendieta Eduardo (eds.) From alienation toforms of life: the critical theory of Rahel Jaeggi. The Pennsylvania State University Press, University Park, pp. 15-40

Kidd Ian James, Medina José, Pohlhaus Jr Gail (eds.) (2017) The Routledge handbook of epistemic injustice. Routledge, London

Laitinen A (2015) Social pathologies, reflexive pathologies, and the idea of higherorder disorders. In: Stud Soc Political Thought 25:44-65

Marx K (1972a) Zur Judenfrage. In: Marx-Engels-Werke, vol 1. Dietz, Berlin

Marx K (1972b) Zur Kritik der Hegelschen Rechtsphilosophie. In: Marx-EngelsWerke, vol 1. Dietz, Berlin

Marx K (1983) Die deutsche ideologie. In: Marx-Engels-Werke, vol 3. Dietz, Berlin

Marx K (1985) Ökonomisch-philosophische Manuskripte. In: Marx-Engels-Werke, vol 40. Dietz, Berlin

Medina J (2013) The epistemology of resistance: gender and racial oppression, epistemic injustice, and resistant imaginations. Oxford University Press, Oxford

Renault E (2017) Social suffering: sociology, psychology, politics. Rowman \& Littlefield, London/New York

Renault E (2020) Critical theory, social critique and knowledge. In: Crit Horizons 21(3):189-204

Rousseau J-J (1996) On the social contract. In: Gourevitch Victor (ed.) Rousseau: the social contract and other later political writings. Cambridge University Press, Cambridge

Rousseau J-J (1997) Discourse on the origin and foundations of inequality among men. In: Gourevitch Victor (ed.) Rousseau: the discourses and other early political writings. Cambridge University Press, Cambridge

Ruda F (2011) Hegel's rabble: an investigation into Hegel's Philosophy of Right. Bloomsbury Continuum, London/New York

Stahl T (2017) Immanent critique and particular moral experience. In: Crit Horizons https://doi.org/10.1080/14409917.2017.1376939

Zurn C (2011) Social pathologies as second-order disorders. In: Petherbridge Danielle (ed.) Axel Honneth: critical essays. With a reply by Axel Honneth. Brill Academic Publishers, Leiden

\section{Competing interests}

The author declares no competing interests.

\section{Additional information}

Correspondence and requests for materials should be addressed to G.C

Reprints and permission information is available at http://www.nature.com/reprints

Publisher's note Springer Nature remains neutral with regard to jurisdictional claims in published maps and institutional affiliations.

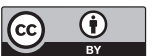

Open Access This article is licensed under a Creative Commons Attribution 4.0 International License, which permits use, sharing, adaptation, distribution and reproduction in any medium or format, as long as you give appropriate credit to the original author(s) and the source, provide a link to the Creative Commons license, and indicate if changes were made. The images or other third party material in this article are included in the article's Creative Commons license, unless indicated otherwise in a credit line to the material. If material is not included in the article's Creative Commons license and your intended use is not permitted by statutory regulation or exceeds the permitted use, you will need to obtain permission directly from the copyright holder. To view a copy of this license, visit http://creativecommons.org/ licenses/by/4.0/.

(C) The Author(s) 2021 